WojCIECH BAŁUS

\title{
TURNING POINTS, CRISES, EVOLUTIONS
}

The curtain with its flight of birds of Paradise blew out again. And Clarissa sawshe saw Ralph Lyon beat it back, and go on talking. So it wasn't a failure after all! It was going to be all right now-her party. It had begun. It had started. But it was still touch and go. She must stand there for the present. People seemed to come in a rush. Colonel and Mrs. Garrod... Mr. Hugh Whitebread... Mr. Bowley... Mrs. Hilbery... Lady Mary Maddox... Mr. Quin... intoned Wilkins. She had six or seven words with each, and they went on, they went into the rooms; into something now, not nothing, since Ralph Lyon had beat back the curtain. ${ }^{1}$

Most likely, this quotation from Virginia Woolf's Mrs. Dalloway is well remembered by every reader of Wiesław Juszczak's book Zasłona $w$ rajskie ptaki [A Curtain with the Birds of Paradise] which unfortunately has been almost forgotten by scholars. In his book, Juszczak analyzed Woolf's novel as an example of modernism. In his view, not only did she want to tell the story about how Clarissa Dalloway organized her party, but also present on a deeper, covert level an artistic process of form making as the goal of art. A banal gesture of beating back a yellow chintz curtain has been interpreted as a moment when the incoherent elements of a composition, i.e., a party, suddenly began to form a whole. Juszczak argued that Woolf did the same, quite openly, in her next novel, To the Lighthouse, where fulfilling a promise to go for a sea trip coincided in the last paragraph of the book with Lily Briscoe's finishing of her landscape painting:

Quickly, as if she were recalled by something over there, she turned to her canvas. There it was-her picture. Yes, with all its green and blues, its lines running up and across, its attempt at something. ... She looked at the steps; they were empty;

\footnotetext{
${ }^{1}$ V. Woolf, Mrs. Dalloway, London 1960, p. 187.
} 
she looked at her canvas; it was blurred. With a sudden intensity, as if she saw it clear for a second, she drew a line there, in the centre. It was done; it was finished. Yes, she thought, laying down her brush in extreme fatigue, I have had my vision. ${ }^{2}$

It was important for Juszczak to demonstrate that self-reflexivity, presentation of the very process of achieving the goal of creation, was out of the question in the $19^{\text {th }}$ century and became possible in the age of modernism since only then form and the self-reflexivity of literature, painting or music became "visible," prominent in the work's texture. They were no longer hidden behind the veil of "realistic" story-telling; no longer transparent in respect to a sublime or down-to-earth subject matter and narration referring exclusively to the outside world and human experience. ${ }^{3}$ That is why Juszczak did not analyze more deeply the gist of Ralph Lyon's beating back the curtain and the nature of the moment when Lily Briscoe made her final brushstroke. He was interested in those circumstances only insofar as they contributed to the completion of the work as form. Still, both events described by Virginia Woolf pertain to something unique and much more fundamental than the characteristics of modernism: the moment of essential change in any process of creation.

Finishing a painting seems easier to understand. All of a sudden, the ultimate "painterly determination of the canvas" - to use the favorite phrase of Polish colorists - just happens. The long lasting impotence is overcome and the goal is accomplished: finis coronat opus. Yet one aspect of that event remains mysterious: what is the origin of that glimpse when everything comes together?

The case of Clarissa Dalloway is perhaps a little more difficult. She also wants to cope with some problem, but it is not purely artistic in nature. No matter if, following Juszczak, we consider the party as a metaphor of creation or, literally, as socializing, the beating back of the curtain will definitely be irrational - not as a banal fact of eliminating an inconvenience, but because of the outcome of that gesture from the character's point of view. When Clarissa has noticed it, her temper changes and, consequently, she changes her approach to the event. Suddenly, she starts controlling the entire party, which means that reaching the assumed goal will no longer be doubtful. It is not hard to explain why the curtain's opening made Mrs. Dalloway sure that the party would be successful, either. That gesture might have made her realize - half consciously - that the atmosphere of the meeting was good. The guest made a natural, free move that meant relaxation and not tension which could

\footnotetext{
${ }^{2}$ V. Woolf, To the Lighthouse, London 1962, p. 242.

${ }^{3}$ W. Juszczak, Zasłona w rajskie ptaki, Warszawa 1981, p. 12.
} 
result, for instance, in an angry reaction to the faux pas of the hostess' failure to put the unruly curtain under control. ${ }^{4}$ What is irrational is noticing that minor fact as such. If in the case of Lily Briscoe the problem was how the instant of fulfilment comes into being, then the question is: why at some particular moment we happen to look at that, and not any other, point in space? After all, if Clarissa Dalloway had not looked at Ralph Lyon, her unhappy consciousness of the party's maker would not have changed.

The episodes from Virignia Woolf's novel must be somehow called and analyzed in detail. In the first place, their common features must be identified. First (1), both events could occur only because they were temporal in character, because time was the background against which they unfolded. Second (2), both of them were targeted, i.e., their goal was to end a process that was unfolding in time. Third (3), accomplishing that goal was uncertain. However (4), that uncertainty was eliminated by a sudden change which resulted in a happy end. Finally (5), the very moment of change was hard to explain in causal terms since it happened abruptly, with no distinct efforts taken by the characters. The only difference was the distance between the characters and their goal: in the case of Lily Briscoe, it was the moment just before the ultimate fulfilment, while Clarissa's party was only "gaining momentum" and it was still "suspended in uncertainty." Besides, both episodes consist of two stages which stand out when the goal is being accomplished (1), i.e., when the plan is being finalized (2). The first stage is marked by an impasse, uncertainty, loss of direction, and, consequently, anguish (3). In the second stage, that predicament is solved (4) by a sudden revelation (5), i.e., realizing that everything moves in the right direction.

The first stage can be defined as a crisis since this concept refers to uncertainty, suffering or tension caused by uncertain future which cannot be anticipated (3)..$^{5}$ In the state of crisis, the goal (2) becomes less distinct while the means to reach it are no longer obvious. It was the period when Lily Briscoe could not finish her painting, and Clarissa Dalloway saw a possibility of social failure. The second stage is that of a turning point, i.e., according to Webster's New Collegiate Dictionary, "an act or point of breaking through an obstruction." ${ }^{6}$

${ }^{4}$ Juszczak interprets this gesture as so natural that it reveals the artificiality of the party as a ritual, which allows Clarissa to perceive it as form which slowly begins to acquire completeness. See Juszczak, Zasłona $w$ rajskie ptaki, p. 85.

${ }^{5}$ R. Koselleck, "Einige Fragen an die Begriffsgeschichte von 'Krise,'” in: Über die Krise. Castelgandolfo-Gespräche 1985, ed. K. Michalski, Stuttgart 1986, p. 64.

${ }^{6}$ Webster's New Collegiate Dictionary, Springfield, MA, 1980, p. 135. 
A turning point can be connected with a crisis in two ways. On the one hand, both terms can have the same meaning. In ancient Greece, and then in early Christianity and the Middle Ages, the noun крírı meant an ultimate, irrevocable solution, the emergence of one of two mutually exclusive elements of an alternative: a victory or a defeat in battle, a recovery or death in the Hippocratic medicine, salvation or damnation in theology, i.e., everything that today we would rather call a turning point. ${ }^{7}$ On the other, the two terms can refer to two different stages of a course of events. If a political crisis means a collapse of a certain policy; a government crisis the fall of a cabinet which lost majority support in the parliament; a scientific crisis a situation when received theories prove unable to account for newly discovered facts; a cultural crisis a period when "current values have failed while there are still no new ones which could take their place," ${ }^{\prime 8}$ all of them refer to an initial stage of upcoming havoc that can be put under control only after some short or long period of time. In this sense, a crisis is a kind of rising wall or other obstacle, while a turning point means breaking through that obstacle toward a preconceived goal. ${ }^{9}$ This is precisely the situation described in Virginia Woolf's novel. There a turning point is an irrational moment (5) when a crisis is resolved thanks to a solution which leads to finishing the painting or realizing for good that the party will be successful. Such a unique moment was considered in ancient Greece an intrusion of another, unusual kind of time. The linear, continuous time, $\chi \rho o ́ v o \varsigma$, opened to a unique, unrepeatable possibility, a wonderful coincidence called kaıpós. ${ }^{10}$

The episodes described by Virginia Woolf focused on individual problems with the process of creation. The impasse in painting a landscape or preparing a party was a state of crisis from which the only way out was through an unexpected revelation of a solution or the rise of confidence that everything moves in the right direction. In both cases, a turning point was necessarily related to a preceding crisis, since if everything went on normally and the painting and the party were realized within the common time filled with work - the chronos, in which there is no room for stops, breakdowns, and uncertainty, then there would be no chance for the intervention of the kairos. ${ }^{11}$

7 See Koselleck, "Einige Fragen an die Begriffsgeschichte...," pp. 64-65.

8 "Kryzys," in: Nowa encyklopedia powszechna PWN, vol. 3, Warszawa 1998, p. 586.

9 H. G. Evers, "Historismus," in: Historismus und bildende Kunst (Studien zur Kunst des 19. Jahrhunderts, vol. 1), ed. L. Grote, München 1965, p. 30.

10 S. Bielecki, "Kairos (1)," in: Encyklopedia Katolicka, vol. 8, Lublin 2000, col. 324.

${ }^{11}$ In Corpus Hippocraticum there is written: "Chronos is that in which there is kairos, and kairos is that in which there is little chronos", see: G. Agamben, The Time that 
In art history, turning points related to historical processes are more significant than the cases of individual artists. Giorgio Vasari knew about it when he wrote:

That very same debt painters owe to Nature, ... is also owed, in my opinion, to Giotto, the Florentine painter; for when the methods and outlines of good painting had been buried for so many years by the ruins of war, he alone, although born among inept artists, revived through God's grace what had fallen into an evil state and brought it back to such a form that it could be called good. And it was truly an extraordinary miracle that such an ignorant and incompetent age could have inspired Giotto to work so skilfully that drawing, of which men during those times had little or no knowledge, came fully back to life through his efforts. ${ }^{12}$

Vasari called that turning point, a "miracle" made by Giotto, "Renaissance," making the word "rinascita" acquire the meaning of a moment of change when undoubtedly the kairos intruded into chronological history. It was thanks to that turning point that in the following decades art could gradually achieve perfection which culminated in the perfezzione of the $16^{\text {th }}$ century ${ }^{13}$ :

Hence, Cimabue was, in one sense, the principal cause of the renewal of the art of painting, but Giotto, though his follower, inspired by a praiseworthy ambition and helped by Heaven and his own natural talent, was the man whose thoughts rose even higher and who opened the gates of truth to those painters who have subsequently brought the art of painting to that level of perfection and grandeur at which we see it in our own century. ${ }^{14}$

The idea that art could raise from decline either thanks to one person or a collective effort returned repeatedly in the following centuries. It implied a question whether such a transformation could be effected on one's own, or only at some propitious moment. In his programmatic pamphlet titled In

Remains. A Commentary on the Letter to the Romans, trans. P. Dailey, Stanford 2005, pp. 68-69.

${ }^{12}$ G. Vasari, The Lives of the Artists, trans. J. Conway Bondanella and P. Bondanella, Oxford 1998, p. 15.

${ }^{13}$ H. Karge, "Renaissance. Aufkommen und Entfaltung des Stilbegriffs in Deutschland im Zuge der Neorenaissance-Bewegung um 1840," in: Neorenaissance - Ansprüche an einen Stil. Zweites Historismus-Symposium Bad Muskau. Muskauer Schriften, vol. 4, eds. W. Krause, H. Laudel, W. Nerdinger, Zittau 2003, pp. 40-41.

${ }^{14}$ Vasari, The Lives of the Artists, p. 13. 
What Style Should We Build?, published in 1828, Heinrich Hübsch wrote: "Painting and sculpture have recently abandoned passive imitation of the ancient times. Only architecture is still dependent, continuing the imitation of the ancient style." ${ }^{15}$ On the contrary, almost one hundred years later Vassily Kandinsky stressed the role of the individual active in the kairos:

Veiled in obscurity are the causes of this need to move ever upwards and forwards, by sweat of the brow, through sufferings and fears. When one stage has been accomplished, and many evil stones cleared from the road, some unseen and wicked hand scatters new obstacles in the way, so that the path often seems blocked and totally obliterated. But there never fails to come to the rescue some human being, like ourselves in everything except that he has in him a secret power of vision. He sees and points the way. ${ }^{16}$

Vasari was the first to interpret a turning point in art as overcoming a bad situation similar to an impasse in an individual artistic development. That state could be improved only by a radical rejection of the present condition. On the other hand, such a negatively valued situation could be more serious than a crisis - it could be a collapse, a total failure. In such terms Vasari referred to the Middle Ages. Hübsch was less pessimistic about contemporary architecture, while Kandinsky definitely analyzed the present in terms of crisis. The upcoming change meant abandoning the nineteenth-century historicism and academism, as well decadentism which was characteristic of the years before $1900 .{ }^{17}$ At any rate, however, connecting a turning point as salvation with an undesirable preceding state of affairs implies that the idea of fundamental transformation could operate only with a system of values that assumed the differences between good and bad art, norm and anti-norm, prosperity and decadence.

Getting rid of the fetters of bad art was usually considered a purely artistic task to be performed by a particular group or a group with a special leader, supported by the kairos. The $20^{\text {th }}$ century added to it a belief that a turning point could occur due to a political decision. When Włodzimierz Sokorski, deputy minister of culture in communist Poland, claimed in 1950 that "epigones of the formalist schools in art argued some time ago that the current crisis in

${ }^{15}$ H. Hübsch, In welchem Style sollen wir bauen?, Karlsruhe 1828, p. 1.

${ }^{16}$ W. Kandinsky, Concerning the Spiritual in Art, trans. M. T. H. Sadler, p. 13, < http:// www.semantikon.com/art/kandinskyspiritualinart.pdf $>$ [last accessed: 13.06.2019].

17 Ibidem, p. 10. On decadentism, see M. Porębski, Ikonosfera, Warszawa 1972, pp. 242-243. 
painting is a result of the exhaustion of conventions, ${ }^{18}$ he both pointed at an undesirable condition and at the real culprits. By the same token, he clearly declared that the only solution was proclaiming the "proper" art by decrees since that would be a remedy for the crisis and a way to crush the useless, annoying "epigones."

Vasari knew that perfection in art is not permanent and that culture develops in cycles, which may lead to another fall. ${ }^{19}$ About 150 years later, Giambattista Vico represented a similar line of reasoning, assuming that the course of culture (corso) may lead to exhaustion followed by a return of barbarism (ricorso) which in fact is a renaissance - a beginning of another cycle, just like the Roman Empire was followed by the Christian Middle Ages. ${ }^{20}$ Kandinsky wrote that the "work of art is the child of its age," ${ }^{21}$ which means that he believed that no turning point could result in ultimate solutions in art. His opinions were based on the idea of crisis as something repetitive, conditioned by continual changes in human history. ${ }^{22}$ This idea was developed by Jacob Burckhardt already in the $19^{\text {th }}$ century - the Swiss historian treated crises as subsequent "knots of development," i.e., moments when old systems of values were replaced by new ones, but he did not claim that any new cultural or political formation could put an end to transformations. ${ }^{23}$ On the contrary, revolutions, starting with Robespierre, interpreted themselves as ultimate turning points that eventually solved all problems of humanity. ${ }^{24}$ This is also how the proclamation of the socialist realism is the late 1940s in Poland must be approached. The kairos was replaced by historical necessity. ${ }^{25}$

Both for artists and politicians, art can be clearly defined in terms of values. It is good or bad, innovative or imitating, ideologically proper or improper. Thus, the concepts of progress, perfection, crisis, decadence, and collapse are crucial for its description. A turning point is perceived as a change for the better, a moment of overcoming an impasse or putting an end to a downfall. Most certainly, such a change will never be absolute or ultimate. As an effect

18 W. Sokorski, "Kryteria realizmu socjalistycznego," in: Czas debat. Antologia krytyki artystycznej z lat 1945-1954, vol. 2: Realizm i formalizm, eds. A. Pietrasik, P. Słodkowski, Warszawa 2016, p. 386.

19 Vasari, The Lives of the Artists, pp. 5-6.

20 See G. Vico, La scienza nuova, Milano 1959, pp. 166-167, 509.

${ }^{21}$ Kandinsky, Concerning the Spiritual..., p. 10.

22 See Koselleck, "Einige Fragen an die Begriffsgeschichte...," p. 68.

${ }^{23}$ See Z. Kuderowicz, Biografia kultury. O pogladach Jakuba Burckhardta, Warszawa 1973, pp. 135-140.

${ }^{24}$ See Koselleck, "Einige Fragen an die Begriffsgeschichte...," p. 72.

25 See K. Popper, The Poverty of Historicism, London and New York 1961, pp. 42-49. 
of a certain artistic or political program, it will be highly appreciated by the advocates of a given ideological change. An adversary of historicism would never be able to approve of Hübsch's Rundbogenstil, just as the socialist realism could be accepted only by a Stalinist or someone who hoped to benefit from it in one way or another.

\section{III}

Since Alois Riegl made the evaluation of historical styles relative by making them equal, the problem of crises and turning points either had to disappear from art history, or acquire a new status free of value judgments. Likewise, scholars had to cope with the concept of continuous development, an unbroken stream of human generations that created new works of art without rejecting the heritage of their ancestors. Since, as Henri Focillon has put it, forms have their own life, growing one out of another, does the continuous course of their changes allow for any discontinuities, leaps or crises? If Rembrandt's painting grows out of the "abundance of his sketches" and all his earlier works that shaped his style anticipated his later works, ${ }^{26}$ how is it possible to find in it the moments of crisis?

For Focillon, there was no such problem since he believed that the continuous development of art was structured by subsequent stylistic formations swiftly passing from one to another and always consisting of four stages: the stage of experiment and exploration, classic, sophisticated, and baroque. ${ }^{27}$ Repetitive cycles eliminated any possible collapse of chronological time. ${ }^{28}$ Max Dvořák in his study of the art of the Van Eyck brothers approached the problem quite differently. ${ }^{29}$ On the one hand, he had no doubts that Jan van Eyck brought about a turning point in painting, achieving an unprecedented quality of naturalism, yet on the other - it was the gist of Dvořák's study Das Rätsel der Kunst der Brüder van Eyck - the new style was an outcome of a long process of development, initiated by the reception of the fourteenth-century Italian art in France and the rise of the so-called Franco-Flemish art. Thus, a revolution turned out to have been an evolution. ${ }^{30}$

26 See H. Focillon, Vie des formes, Paris 1934, p. 10.

27 See ibidem, p. 14.

${ }^{28}$ See H. Belting, Das Ende der Kunstgeschichte. Eine Revision nach zehn Jahren, München 2005, pp. 145-146.

29 M. Dvořák, Das Rätsel der Kunst der Brüder van Eyck, München 1925.

${ }^{30}$ L. Kalinowski, Max Dvořák i jego metoda badań nad sztuka, Warszawa 1974, pp. $17-$ 21; A. Rosenauer, "Das Rätsel der Kunst der Brüder van Eyck - Max Dvořák und seine Stellung zu Wickhoff und Riegl," in: Wien und die Entwicklung der kunsthistorischen Methode, 
Dvořák's solution resembles a paradox formulated by Aristotle at the end of Posterior Analytics. As he wrote, "when a rout has occurred, first one man takes a stand, then another does, and then another, until a position of strength is reached." 31 Even though a turning point actually occurs, when watching combat, it is hard to determine at what specific moment the soldiers' escape turned into their return to battle. A statement that at some point a decisive turn took place can be made only ex post. It is quite similar in art: assuming its historical character and following its transformations in time, we can acknowledge only its evolution. More or less radical changes can be noticed only from a superior point of view from which we can see certain closed units emerging in the course of time, and from a point that is chronologically distant, which makes those units even more distinct. Sometimes, particularly in the case of extinct civilizations whose history cannot be reconstructed for the lack of sources, the only available clue is a trace of some obscure change noticeable in the surviving artifacts. George Kubler wrote:

The annals of art, like those of bravery, directly record only a handful of the many great moments that have occurred. When we consider the class of these great moments, we are usually confronted with dead stars. Even their light has ceased to reach us. We know of their existence only indirectly, by their perturbations, and by the immense detritus of derivative stuff left in their paths. ${ }^{32}$

On the one hand, scholars focusing on historical processes identify specific turning points, on the other, they find their origin. Yuri Lotman wrote:

The historian regards an event from a point of view which is oriented from present to past. This view, by its very nature, transforms the object of description. The picture of events, which appears chaotic to the casual observer, leaves the hands of the historian in the form of a secondary organization. It is natural for the historian to proceed from the inevitability of what has occurred. However, his creative activity is manifested in other ways: from the abundance of facts stored in memory, he constructs a sequential line, leading with the utmost reliability towards this conclusive point [i.e., toward a turning point - W. B.]. ${ }^{33}$

eds. S. Krenn, M. Pippal (Akten des XXV. Internationalen Kongresses für Kunstgeschichte, Wien, 4.-10. September 1983, eds. H. Fillitz, M. Pippal, vol. 1), Wien-Köln-Graz 1984, pp. 45-52; H. Aurenhammer, "Max Dvořák (1874-1921). Von der historischen Quellenkritik zur Kunstgeschichte als Geistesgeschichte," in: Österreichische Historiker. Lebensläufe und Karrieren 1900-1945, vol. 2, ed. K. Hruza, Wien-Köln-Weimar 2012, pp. 185-190.

31 Aristotle, Posterior Analytics, trans. J. Barnes, Oxford 2002, 2, 100a (p. 73).

32 G. Kubler, The Shape of Time. Remarks on the History of Things, New Haven and London 1970, p. 40.

33 Y. Lotman, Culture and Explosion, trans. W. Clark, Berlin and New York 2009, p. 17. 
For Dvořák writing about the Van Eyck brothers' a revolution was just some kind of "fold" on the smooth course of the continuous, autonomous, and intrinsic evolution of style. A turning point did not depend on a preceding crisis. However, several years later he claimed that a radical change in art was always brought about by causes rooted in human thought, i.e., in worldviews. ${ }^{34}$ They could either result in replacing one spiritual formation with another with no symptoms of crisis, or in a collapse of the ruling system of culture. The first process was illustrated by the birth of the Christian art which took three hundred years. The victory of a new kind of art meant the end of the ancient naturalism and the cult of the body in favor of the spirit. An evolution brought a revolution again, yet in that case it was not interpreted as an autonomous phenomenon within art itself but as an effect of external causes. Dvořák argued:

The catacomb painting was able to move that far since it was based on a transcendent Christian worldview that allowed artists to ignore material, sensual activity and the rules of nature. Such radicalism brought about - gradually, but from the very beginning - to a sharp opposition between the catacomb painting and the contemporary pagan art. In the anti-materialist bias of its new tendencies Christianity found an approach to art that could be combined with the Christian approach to the world..$^{35}$

The other case was related to mannerism. That phenomenon in art, which in the early $20^{\text {th }}$ century was still valued negatively, Dvořák interpreted as a crisis caused by doubt about the rationalism of high Renaissance. In his opinion, that crisis implied also a positive turn toward spiritual values and idealism. It was not solved in the $16^{\text {th }}$ century and the following ones since in that period the rationalist tendencies prevailed again. ${ }^{36}$ However, it returned after World War I with expressionism and then led, according to Dvořák, to a radical shift in the dominant worldview. Analyzing a cycle of Kamilla Svoboda's graphic portraits by Oskar Kokoschka from 1920, he wrote:

${ }^{34}$ Kalinowski, Max Dvořák i jego metoda..., pp. 22-32; J. Bakoš, "Die epistemologische Wende eines Kunsthistorikers," in: L'Art et les révolutions, Section 5: Révolution et évolution de l'Histoire de l'Art de Warburg à nos jours, ed. H. Olbrich, Strasbourg 1992, pp. 43-72; Aurenhammer, "Max Dvořák (1874-1921)," pp. 194-200.

35 M. Dvořák, "Katakombenmalereien. Die Anfänge der christlichen Kunst," in: idem, Kunstgeschichte als Geistesgeschichte. Studien zur abendländischen Kunstentwicklung, München 1924, p. 33.

${ }^{36}$ M. Dvořák, "Über Greco und den Mannerismus," in: ibidem, pp. 270-271 and 275276; W. Bałus, "Max Dvořák betrachtet Tintoretto oder über den Manierismus, " Ars 2011, 44, pp. 32-35. 
Thus Kokoschka's Variations stand simultaneously between two periods; they represent a turning point, a fruit of the previous revolutionary moment, but at the same time they are step towards a future realm of a new German idealism that will be founded not on the world of the senses but will take its ideal forms from the spheres of the spirits. ${ }^{37}$

The problem of turning points was approached quite differently in the theories which assumed cyclical succession of the stages of development. Mieczysław Porębski, who believed in generational rhythms, claimed that each generation first defines its views in respect to received ideas and the puts them to test in practice. This, he argued, is the reason why every dozen years or so there are crises caused by the appearance of another generation or the attempts made by the previous one to revise their opinions. The result is the "descending and ascending rhythm of sharp, spectacular crises connected with significant socio-political events." ${ }^{38}$ In that case, crises and turning points were not considered in terms of values. Porębski interpreted them only as symptoms of intellectual changes characteristic of the subsequent generations of culture makers. Hence, a historical perspective brought another interpretation of turning points. First, abandoning an evaluative approach to epochs and styles eliminated from the historical process "bad" art, and consequently also the times of crisis and decline. By the same token, the problem of the goal of the evolution of art was gone. The only task left to art historians was to acknowledge changes, i.e., to describe how a new formation replaced an earlier one. The concept of crisis could be applied only as an analytical term referring to some minor phenomenon with a specific aesthetic program, i.e., as a local instrument with no universal significance (e.g., the crisis of academism) or as an element of a cycle in the theories that assumed the rhythmic quality of historical processes. Also sudden, unexpected changes which triggered the rise of a new tendency or style (e.g., the appearance of the gothic style in Île-de-France in the $12^{\text {th }}$ century) was interpreted as a peculiar kind of crisis. Following Carl Friedrich von Weizsäcker, Jan Białostocki called it "fulguration." ${ }^{39}$

Second, the treatment of the past as a continuous, unbroken process of events resulted in relativization of its own kind. Observed from a distance, such historical material could be ordered in different ways. Kubler argued that works of art could be placed in different series of historical processes (e.g., the

${ }^{37}$ M. Dvořák, "Foreword to Oskar Kokoschka: Variations on a Theme" [1921], trans. H. Mathews, in: The Expressionist Turn in Art History. A Critical Anthology, ed. K. A. Smith, London and New York 2017, p. 234.

${ }^{38}$ M. Porębski, "Rytmy historii," in: idem, Interregnum. Studia z historii sztuki polskiej XIX i XX W., Warszawa 1975, p. 273.

39 J. Białostocki, "Krisen in der Kunst," in: Über die Krise, pp. 175-176. 
Il Gesú church could be put at the beginning of a new type of the Jesuit church, or considered as an element in the development of early modern church architecture or stone and brick architecture in general)..$^{40}$ Their crucial character can be prominent in certain series while in others it may be quite insignificant. Lotman wrote: "Culture, whilst it is a complex whole, is created from elements which develop at different rates, so that any one of its synchronic sections reveals the simultaneous presence of these different stages. Explosions in some layers may be combined with gradual development in others." ${ }^{41}$

Third, turning points lost their significance due to the processes of "normalization." As long as we consider an epoch, a type of culture or a kind of art as special, our situation is similar to that of Vasari: we may call it either as particularly valuable or as valueless. Dvořák did not condemn antiquity so that the transition from the pagan Roman art to Christian catacomb painting could not be evaluated in terms of "better or worse." On the other hand, since in mannerism he saw the beginning of an idealistic attitude which he endorsed, in his paper on Kokoschka he clearly returned to the schema known from Vasari's Lives: something undesirable and valued negatively (dull, scientific rationalism) changed under his eyes for the better thanks to the expressionist revolution. However, if we approach mannerism as a standard element of art history, its special significance will automatically disappear. Still, the question is whether such a normalizing approach is always appropriate. If yes, what will the future historians do with such declarations as that of Sokorski and turning points such as the proclamation of the socialist realism?

IV

To sum up: in the individual artistic development, turning points are related to crises and impasses, i.e., to finding ways that lead to a goal again. Quite often, such moments of finding happen suddenly, at some special moment called by the Greeks the kairos. Changes in art considered en bloc also occur thanks to specifying some goal, which is always connected to values. Such changes can be either interpreted as overcoming a crisis or as putting an end to the state of decline or decadence, always valued negatively. Definitely, a separate case is the political proclamation of a change, which is always an act of symbolic violence. Finally, in academic art history a turning point, defined in relative terms, does not have to be connected to a crisis. Therefore, art history can be rewritten again and again.

\footnotetext{
${ }^{40}$ See Kubler, The Shape of Time, pp. 33-39.

${ }^{41}$ Lotman, Culture and Explosion, p. 12.
} 


\section{BIBLIOGRAPHY}

Agamben G., The Time that Remains. A Commentary on the Letter to the Romans, trans. P. Dailey, Stanford 2005

Aristotle, Posterior Analytics, trans. J. Barnes, Oxford 2002

Aurenhammer H., "Max Dvořák (1874-1921). Von der historischen Quellenkritik zur Kunstgeschichte als Geistesgeschichte," in: Österreichische Historiker. Lebensläufe und Karrieren 1900-1945, ed. K. Hruza, Wien-Köln-Weimar 2012, vol. 2, pp. $169-200$

Bakoš J., "Die epistemologische Wende eines Kunsthistorikers," in: L'Art et les révolutions, Section 5: Révolution et évolution de l'Histoire de l'Art de Warburg à nos jours, ed. H. Olbrich, Strasbourg 1992, pp. 43-72

Bałus W., "Max Dvořák betrachtet Tintoretto oder über den Manierismus," Ars 2011, 44, pp. 26-43

Belting H., Das Ende der Kunstgeschichte. Eine Revision nach zehn Jahren, München 2005

Białostocki J., "Krisen in der Kunst," in: Über die Krise. Castelgandolfo-Gespräche 1985, ed. K. Michalski, Stuttgart 1986, pp. 162-182

Bielecki S., "Kairos (1)," in: Encyklopedia Katolicka, vol. 8, Lublin 2000, col. 334-337

Dvořák M., "Katakombenmalereien. Die Anfänge der christlichen Kunst," in: idem, Kunstgeschichte als Geistesgeschichte. Studien zur abendländischen Kunstentwicklung, München 1924, pp. 1-40

Dvořák M., Über Greco und den Mannerismus," in: idem, Kunstgeschichte als Geistesgeschichte. Studien zur abendländischen Kunstentwicklung, München 1924, pp. 259-276

Dvořák M., Das Rätsel der Kunst der Brüder van Eyck, München 1925

Dvořák M., "Foreword to "Oskar Kokoschka: Variations on a Theme»" [1921], trans. H. Mathews, in: The Expressionist Turn in Art History. A Critical Anthology, ed. K. A. Smith, London-New York 2017, pp. 231-234

Evers H. G., "Historismus," in: Historismus und bildende Kunst, ed. L. Grote, München 1965 (= Studien zur Kunst des 19. Jahrhunderts, vol. 1), pp. 25-42

Focillon H., Vie des formes, Paris 1934

Hübsch H., In welchem Style sollen wir bauen?, Karlsruhe 1828

Juszczak W., Zasłona w rajskie ptaki albo O granicach „okresu powieści”, Warszawa 1981

Kalinowski L., Max Dvořák i jego metoda badań nad sztuka, Warszawa 1974

Kandinsky W., Concerning the Spiritual in Art, trans. M. T. H. Sadler, p. 13, $<$ http://www.semantikon.com/art/kandinskyspiritualinart.pdf> [last accessed: 13.06.2019]

Karge H., "Renaissance. Aufkommen und Entfaltung des Stilbegriffs in Deutschland im Zuge der Neorenaissance-Bewegung um 1840," in: Neorenaissance - Ansprüche an einen Stil. Zweites Historismus-Symposium Bad Muskau, Dresden 2001 (= Muskauer Schriften, vol. 4, eds. W. Krause, H. Laudel, W. Nerdinger), pp. $39-66$ 
Kosseleck R., "Einige Fragen an die Begriffsgeschichte von 'Krise'”, in: Über die Krise. Castelgandolfo-Gespräche 1985, ed. K. Michalski, Stuttgart 1986, pp. 64-77

"Kryzys", in: Nowa encyklopedia powszechna PWN, Warszawa 1998, vol. 3, p. 586

Kubler G., The Shape of Time. Remarks on the History of Things, New Haven and London 1970

Kuderowicz Z., Biografia kultury. O pogladach Jakuba Burckhardta, Warszawa 1973

Lotman Y., Culture and Explosion, trans. W. Clark, Berlin-New York 2009 (= Semiotics, Communication and Cognition, ed. P. Cobley, vol. 1)

"Przełom," in: Słownik języka polskiego, ed. W. Doroszewski, <https://sjp.pwn.pl/doroszewski/przelom;5484156.html> [last accessed: 2.05.2019]

Popper K., The Poverty of Historicism, London and New York 1961

Porębski M., Ikonosfera, Warszawa 1972

Porębski M., "Rytmy historii," in: idem, Interregnum. Studia z historii sztuki polskiej XIX i XX W., Warszawa 1975, pp. 263-293

Rosenauer A., "Das Rätsel der Kunst der Brüder van Eyck - Max Dvořák und seine Stellung zu Wickhoff und Riegl," in: Wien und die Entwicklung der kunsthistorischen Methode, eds. S. Krenn, M. Pippal (= Akten des XXV. Internationalen Kongresses für Kunstgeschichte, Wien, 4.-10. September 1983, eds. H. Fillitz, M. Pippal, vol. 1), Wien-Köln-Graz 1984, pp. 45-52

Sokorski W., "Kryteria realizmu socjalistycznego," in: Czas debat. Antologia krytyki artystycznej z lat 1945-1954, vol. 2: Realizm i formalizm, eds. A. Pietrasik, P. Słodkowski, Warszawa 2016, pp. 386-393

Vasari G., The Lives of the Artists, trans. J. Conway Bondanella and P. Bondanella, Oxford 1998

Vico G., La scienza nuova, Milano 1959

Webster's New Collegiate Dictionary, Springfield, MA, 1980

Woolf V., To the Lighthouse, London 1962

Woolf V., Mrs. Dalloway, London 1960

Wojciech Bałus

Jagiellonian University, Cracow

\section{TURNING POINTS, CRISES, EVOLUTIONS}

\section{Summary}

When Aristotle asked at what particular moment we can say that an army is fleeing, which is certainly not when individual soldiers start leaving the battlefield, he formulated a problem that is important also for today's art history: are there any moments in the history of art that can be called turning points? In individual artistic careers, such points are related to crises, allowing the artist to overcome an impasse and find a way toward reaching a goal. Quite often, such a turn occurs suddenly, at some particular moment which ancient Greeks called the kairos. The changes in art approached en bloc also happen thanks to the background of values and some goal of artistic creation. 
A turning point may imply overcoming a crisis or a period of decline and decadence - always a state of affairs defined in negative terms. A separate case is definitely a political decree that triggers off a change, which implies violence committed on culture. Finally, in academic art history a turning point may be related not only with a crisis, but also with evolution. It's perception is relative, but because of that the history of art can be rewritten.

Keywords:

turning point, crisis, evolution, kairos, methodology of art history 